\title{
CT-Guided Piriformis Muscle Injection for the Treatment of Piriformis Syndrome
}

\section{Piriformis Sendromu Tedavisinde BT Eşliğinde Piriformis Enjeksiyonu}

\author{
Pinar AKDEMIR OZISIK ${ }^{1}$, Mustafa TORU², C. Cem DENK³, Ozden O.TASKIRAN ${ }^{4}$ Begum GUNDOGMUS ${ }^{4}$ \\ ${ }^{1}$ TDV 29 Mayis Hospital, Department of Neurosurgery, Ankara, Turkey \\ ${ }^{2} T D V 29$ Mayis Hospital, Department of Radiology, Ankara, Turkey \\ ${ }^{3}$ Hacettepe University, School of Medicine, Department of Anatomy, Ankara, Turkey \\ ${ }_{4}^{4}$ DV 29 Mayis Hospital, Department of Physiotherapy and Rehabilitation, Ankara, Turkey
}

Presented in: XXII. Annual Scientific Congress of the Turkish Neurosurgical Society, 18-22 April 2008, Antalya, Turkey.

Corresponding Author: Pınar AKDEMIR OZISIK / E-mail: pinar.akdemir.oz@gmail.com, pozisik@koruhastanesi.com

\begin{abstract}
AIM: Piriformis syndrome is a rare neuromuscular disorder that occurs when the piriformis muscle compresses or irritates the sciatic nerve. The treatment of piriformis syndrome includes injections into the piriformis muscle around the sciatic nerve. These invasive approaches have been used with various techniques to increase the safety of the procedure. Computed tomography (CT)-guided injection of the piriformis muscle and the clinical outcome of the patients are discussed.

MATERIAL and METHODS: The authors presented 10 consecutive patients that underwent CT-guided piriformis injection between March and December 2007. Three patients had a history of a severe fall on the buttocks, one had gluteal abscess formation following deep intramuscular injection, and another one had a habit of prolonged sitting on the carpet. Etiology was not identified in the other patients. Main complaints of the patients were pain and numbness in the legs. Hypesthesia was the major neurological finding. Magnetic resonance imaging (MRI) and electromyography (EMG) were performed in all patients.

RESULTS: Nine patients had full and sustained recovery of their symptoms after piriformis injection. Only the patient who had gluteal abscess formation following deep intramuscular injection showed moderate improvement. Another patient was operated on in the 6th month after piriformis injection due to an extruded disc herniation.
\end{abstract}

CONCLUSION: CT-guided piriformis injection is a safe and effective method in the treatment of piriformis syndrome.

KEYWORDS: Computed tomography, Piriformis syndrome, Sciatica, Treatment

Öz

AMAÇ: Piriformis sendromu, piriformis kasının siyatik sinire bası ya da irritasyonu sonucu, kalçada ve siyatik sinir trasesi boyunca yayılan ağııa neden olan nadir bir nöromusküler sendromdur. Tedavisinde piriformis kasına ve siyatik sinir çevresine enjeksiyonlar yapılmaktadır. Bu invazif girişimler çoğunlukla işlemin güvenliğini arttıracak farklı teknikler kullanılarak yapılmaktadır. Bu makalede, bilgisayarlı tomografi (BT) eşliğinde piriformis enjeksiyonu yapılan hastalar ve prognozları tartışılmıştır.

YÖNTEM ve GEREÇLER: Yazarlar Mart-Kasım 2007 tarihleri arasında BT eşliğinde piriformis enjeksiyonu yapılmış on hastayı sunmaktadır. Üç hastada yüksekten kalça üzerine düşme, bir hastada intramüsküler enjeksiyonu takiben abse gelişimi, bir hastada da sert yerde uzun sureli oturma alışkanlığı öyküleri mevcuttur. Diğer hastalarda etiyoloji belirlenememiştir. Başlıca yakınma bacaklarda ağrı ve uyuşmadır. Hipoestezi ana nörolojik bulgudur, Tüm hastalara lomber manyetik rezonans (MR) ve elektromyonörografi (EMG) yapılmıştır.

BULGULAR: Dokuz hastada piriformis enjeksiyonu sonrası uzun süreli belirgin iyileşme görülmüştür. İntramüsküler enjeksiyonu takiben abse gelişimi öyküsü olan hasta orta derecede fayda görmüştür. Bir başka hasta da piriformis enjeksiyonundan 6 ay sonra lomber disk hernisi nedeniyle opere edilmiştir.

SONUÇ: BT-eşliğinde piriformis enjeksiyonu bu sendromun tedavisinde etkili ve güvenilir bir yöntemdir.

ANAHTAR SÖZCÜKLER: Bilgisayarlı tomografi, Piriformis sendromu, Siyatalji, Tedavi

\section{INTRODUCTION}

Sciatica is characterized by radiating pain from the sacrolumbar region to the buttocks and down to the lower limb. The causes of sciatica are usually related to degenerative changes in the spine and intervertebral discs. Correct diagnosis and successful treatment of patients with sciatica who do not lumbar disc herniation is important, because hundreds of thousands of patients are affected each year. Bernard et al reported the incidence of piriformis syndrome as $0.33 \%$ in 1293 patients with back pain (3). It increases to $5-6 \%$ in different series $(20,21)$. It has remained underestimated, because it is often considered a diagnosis of exclusion. 
Familiarity with the common constituents of the syndrome should increase its recognition and facilitate the appropriate treatment. These include buttock pain and tenderness with or without electrodiagnostic or neurological signs. Pain is exacerbated with prolonged sitting, squatting down, and sometimes when climbing stairs. Specific physical findings are tenderness in the sciatic notch together with buttock pain in flexion, adduction, and internal rotation (FADIR) of the hip. Imaging modalities are rarely helpful, but electrophysiological studies should confirm the diagnosis. Recognition and widespread appreciation of the clinical presentation improves its early detection and accurate treatment.

In this article, the pathophysiology of the syndrome and the safety and efficacy of CT-guided injection of the piriformis muscle will be discussed on the basis of the anatomy and the effects of the drugs, as the piriformis injection causes $8-10 \mathrm{ml}$ extra volume in the muscle and increases the possibility of pressure on the nerve.

\section{MATERIAL and METHODS}

The authors present 10 consecutive patients who underwent a CT-guided piriformis injection between March and December 2007 (Table I). All patients underwent a detailed neurological examination. Patients without adequate imaging data obtained within the last 6 months underwent spinal radiography and MRI. Three patients also underwent pelvic MRI to eliminate intrapelvic lesions causing sciatic nerve pressure and/or invasion. All patients gave written consent for the procedure, and permission from the ethical committee of 29 Mayis Hospital was obtained when the patients' data were collected.
Three patients had a history of a severe fall on the buttocks, and one had gluteal abscess formation following deep intramuscular injection. The etiology was not identified in the other patients. The main complaints of the patients were pain and numbness in the legs, with hypesthesia as the major neurological sign. Pace's (the patient abducts the leg when the thigh is in flexion which causes contraction of the piriformis muscle) and Freidberg's (forceful internal rotation of the extended thigh elicits buttock pain by stretching the piriformis muscle) maneuvers were positive. EMG was also performed in all patients.

10 patients ( 2 males and 8 females; age range 32-65 years) received a piriformis muscle injection. Three of them received an injection to the left piriformis muscle, six had a right-sided injection and one had bilateral injections.

None of the patients had received previous treatments such as epidural, facet, and/or sacroiliac joint (SIJ) injections, or spinal surgery. Six patients had undergone physiotherapy and medical treatment, but they had experienced no relief or could not finish the programme because of pain.

The patient was placed in prone position on the CT table (GE Lightspeed VCT 64, USA). Axial images were taken with a slice thickness of $1 \mathrm{~mm}$ under the multislice CT machine with a grid system made up of radiopaque wires over the buttock area to guide the placement of needle insertion. A sign was placed the skin perpendicular to the piriformis muscle was put with a skin marker. Then the patient was cleaned and covered with sterile drapes. An 18G LP needle was inserted into the piriformis muscle, and needle placement was confirmed with CT. None of our patients had any pain corresponding

Table I: Patient Characteristics

\begin{tabular}{|c|c|c|c|c|c|c|c|}
\hline No & Age & Gender & Etiology & MR & Symptoms & Procedure & Outcome \\
\hline 1 & 65 & M & Falling down & Normal & Pain in both leg, cramps & Bilateral PI & very good \\
\hline 2 & 62 & $\mathrm{~F}$ & $?$ & Normal & Pain & Left PI & very good \\
\hline 3 & 52 & $\mathrm{~F}$ & $\begin{array}{l}\text { Post-injection } \\
\text { gluteal abscess }\end{array}$ & $\begin{array}{l}\text { Right piriformis } \\
\text { muscle hypertrophy }\end{array}$ & Pain & Right PI & medium \\
\hline 4 & 61 & $\mathrm{~F}$ & $\begin{array}{l}\text { Prolonged sitting } \\
\text { on the carpet }\end{array}$ & $\begin{array}{l}\mathrm{L} 5 \text {-S1 left disc } \\
\text { protrusion }\end{array}$ & $\begin{array}{l}\text { Left EHL 3+/5; Left AT 4/5; } \\
\text { L5 hypesthesia }\end{array}$ & Left PI & very good \\
\hline 5 & 63 & $\mathrm{~F}$ & $?$ & Normal & Left L5 hypesthesia & Left PI & very good \\
\hline 6 & 42 & $\mathrm{~F}$ & Falling down & Normal & Right L4, L5 hypesthesia & Right PI & very good \\
\hline 7 & 48 & $\mathrm{~F}$ & $?$ & Normal & Right L5, S1 hypesthesia & Right PI & good \\
\hline 8 & 49 & $\mathrm{~F}$ & Falling down & L4-5 spinal stenosis & $\begin{array}{l}\text { Right L4, L5, S1 } \\
\text { hypesthesia }\end{array}$ & Right PI & good \\
\hline 9 & 32 & $\mathrm{~F}$ & $?$ & $\begin{array}{l}\mathrm{L} 4-5 \text { right disc } \\
\text { protrusion }\end{array}$ & Right L5, S1 hypesthesia & Right PI & $\begin{array}{l}\text { lumbar } \\
\text { discectomy } \\
\text { operation (6 } \\
\text { months later) }\end{array}$ \\
\hline 10 & 64 & M & $?$ & Normal & Pain & Right PI & very good \\
\hline
\end{tabular}

AT: Anterior tibialis muscle; EHL: Extensor hallucis longus muscle; PI: Piriformis injection. 
to their usual pains at this stage except for the pain of the needle. Depomedrol $40 \mathrm{mg} / 1$ vial (Eczacıbaşı, Istanbul) and Marcaine 1 amp (Astra-Zeneca, Istanbul) were administered. When half of the injection was completed, another CT scan was taken to control if there was any problem with the spread of the medication. The injection was discontinued and the procedure completed if there was no problem on the CT scan or any increase in pain.

\section{EXAMPLE CASES}

Patient number 1 was a 65 -year-old male who presented to our hospital as an outpatient with leg cramps for 1.5 years. He had applied to numerous physicians with different specialties in these years, but received neither a diagnosis nor effective treatment. His medical history included falling down from a 3-meter-height on his buttocks 1.5 years ago. Since then, he had been experiencing bilateral leg cramps with certain leg movements. When he squatted down, or raised his legs straight up, he got cramps in his toes and calf muscles with severe pain and numbness in these areas. The numbness of his legs made him wake up at night. He was no longer able to lead his normal life style, work in the garden, or use a squattype toilet for defecation.

No motor deficit was found on neurological examination. He had bilateral L4, L5 and S1 hypesthesia. The straight leg raising test and Freidberg's sign were negative bilaterally, but cramps in the calf and cramp-like flexion of the toes were observed during Pace's maneuver in both legs (Figure $1 A, B)$. EMG and lumbar MRI did not show any abnormality. The patient underwent bilateral piriformis muscle injection under CT guidance with a two-month interval. Figure 2(A, B, C) show the piriformis injection procedure for the right side. Two months later, there was no difference in the thickness of the muscles. The left side was injected, too (Figure 2D). All symptoms and findings resolved within three days following steroid and local anaesthetic drug infusion. 2-year follow-up showed no recurrence of the symptoms.

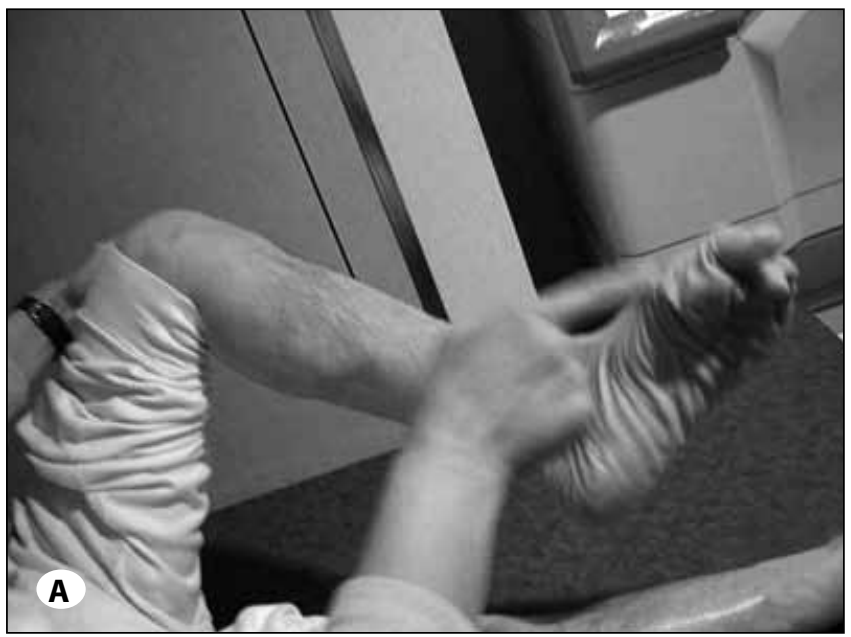

Figure 1: Pictures of Patient 1 during neurologic examination. A, B) Cramps in the calf and cramp-like flexion of the foot fingers were observed during PACE maneuver (active contraction of the muscle) in both legs.

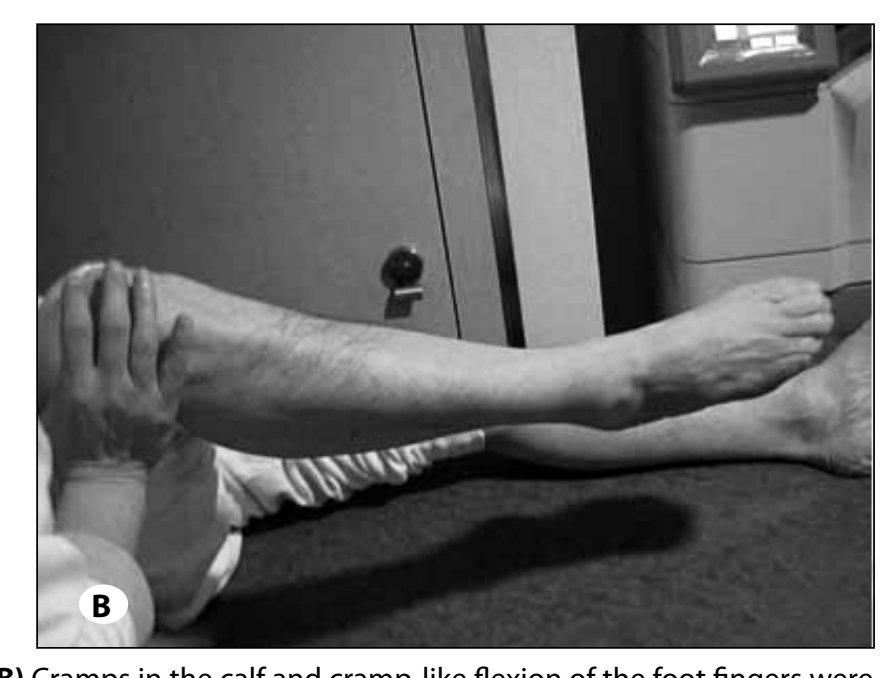

\section{COMPLICATIONS}

During the procedure, patient number 6 had hemorrhage in the right piriformis muscle (Figure 3A,B). She was recommended bed rest and a nonsteroidal anti-inflammatory drug (NSAID). Before injection, she had right sciatica, and L4 and L5 hypesthesia. After 3 days she had no pain, and at 9 months follow-up she had good recovery without numbness in her right leg.

Complications also included numbness in the injection side leg for 6-8 hours in 2 patients. One of them was patient number 4 who had back pain, left sciatica and loss of strength at left extensor hallucis longus (EHL) and anterior tibialis (AT) muscles. Following injection, she had numbness in the left leg for 6-8 hours. After 6 months, she had full recovery of the hypesthesia and loss of strength. Figure $4(A, B)$ shows her lumbar MRI demonstrating disc protrusion at the L5-S1 level which is not correlated with the level of the neurological deficit. We want to highlight the importance of a careful neurological examination, as such patients can be easily operated for the disc herniation. Another example of a similar situation was patient number 9, a 32-year-old young woman, who had right sciatica and L5, S1 hypesthesia. Her MRI showed black discs and slight protrusions at the L4-5 and L5-S1 levels (Figure 5A, B). After a right piriformis injection, her complaints were resolved. She was recommended physiotherapy for lumbar disc protrusion. She had no back and leg pain and continued to work as usual. Six months later, she applied again with sudden right leg pain, L5 and S1 hypesthesia, and motor deficit of the EHL muscle. New MRI images demonstrated increased disc protrusion at the L4-5 level and an extruded disc fragment that had migrated inferiorly in the spinal canal a microlumbar discectomy operation and good recovery. However, resolved pain may sometimes cause patients to neglect recommendations. and pressed on the on right L5 root (Figure 5C,D). She had 

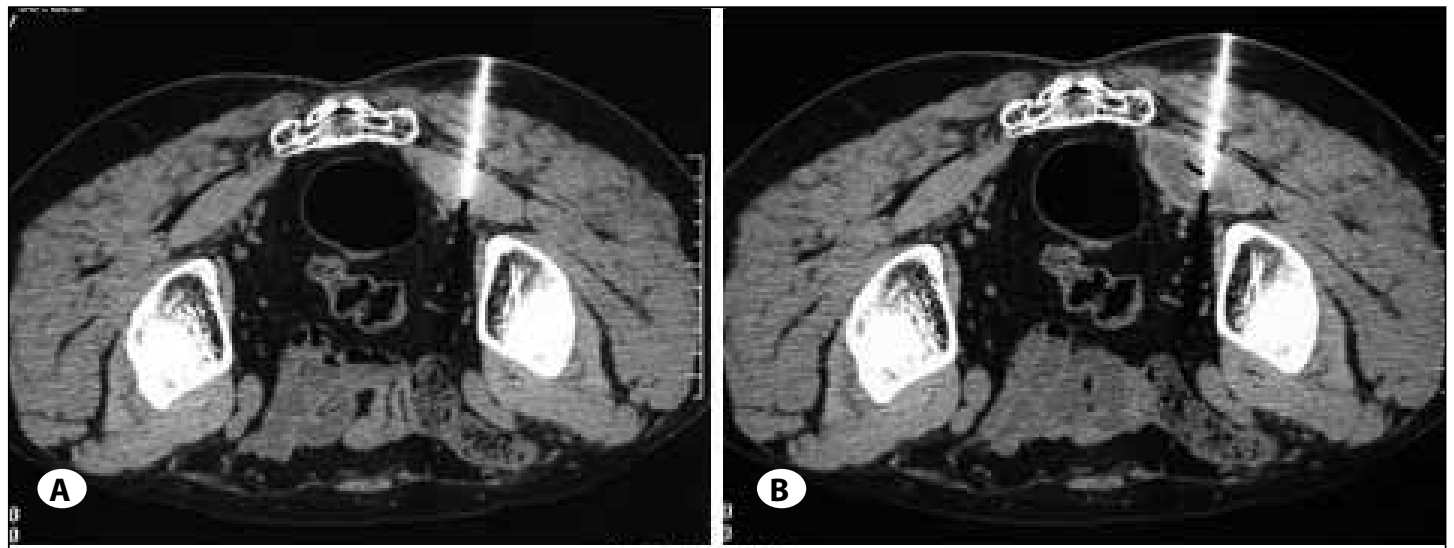

Figure 2: CT

images during

piriformis injection

of Patient 1, right

side.
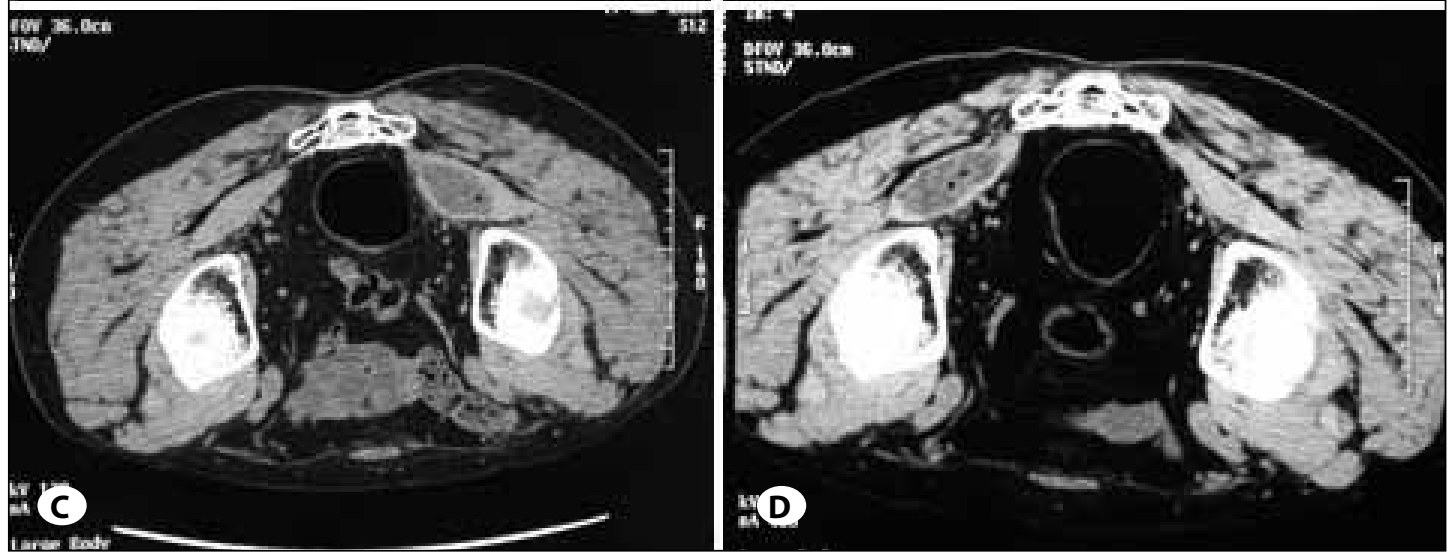

A) Confirmation of needle localization.

B) Check after

3-4 cc injection.

C) Check after

completion of injection, right side. D) CT images during piriformis injection, left side. The right side piriformis muscle, injected 2 months ago, shows regular volume and shape.
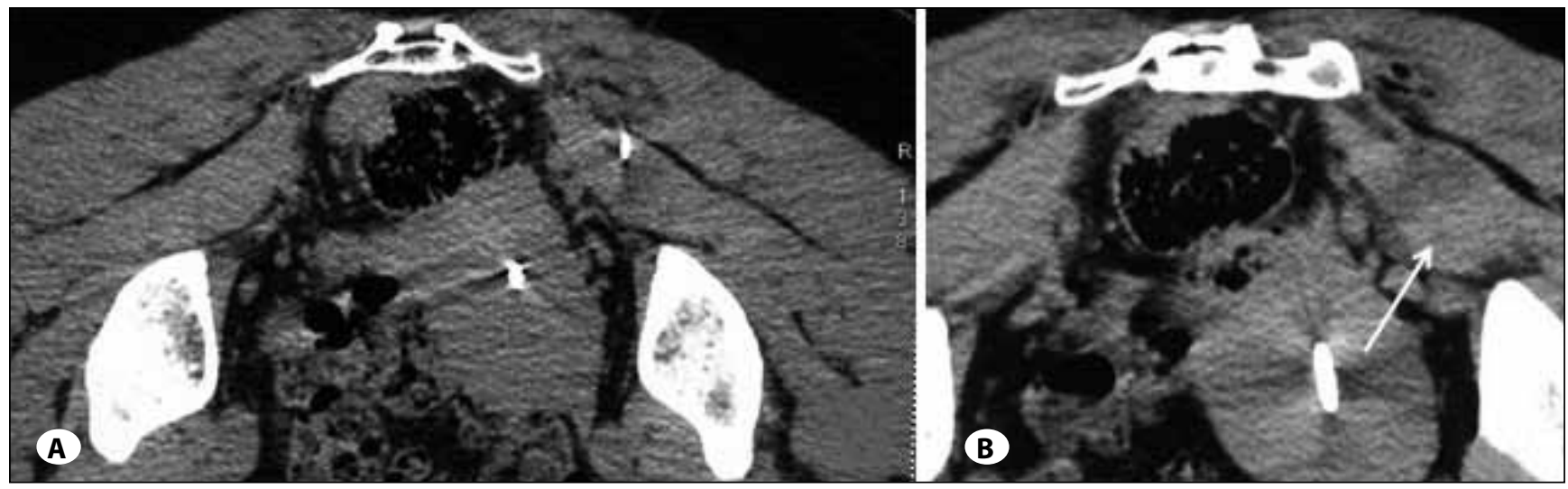

Figure 3: A) CT images of Patient-6 during piriformis injection, right side, localization of needle and beginning of injection. B) Control CT after $3 \mathrm{cc}$ injection (middle of the procedure) showed slight hemorrhage and swallowing of muscle. The injection was stopped and needle was removed.

\section{RESULTS}

The injection procedure took 20 minutes on average after positioning of patient on the CT table. Nine patients had good recovery with 2-year follow-up. Pain was evaluated with the visual analog scale (VAS). In Table I, very good outcome means that the patient has no pain and no neurological symptoms in the legs. Good outcome means that the patient has a pain level between 1 and 3 by VAS, and sometimes numbness in the legs after the injection. The patient who had gluteal abscess formation following deep intramuscular injection (patient number 3 ) did not have sustained relief. She continued to complain of almost the same level of pain.

\section{DISCUSSION}

The piriformis muscle is a pyramid-shaped short but vital muscle. It originates from the anterior surface of the S2-S4 vertebrae, the gluteal surface of the ilium near the posterior surface of the iliac spine, and the capsule of the SIJ $(6,11)$. It runs laterally through the greater sciatic foramen, becomes tendinous, and inserts to the piriformis fossa at the medial 


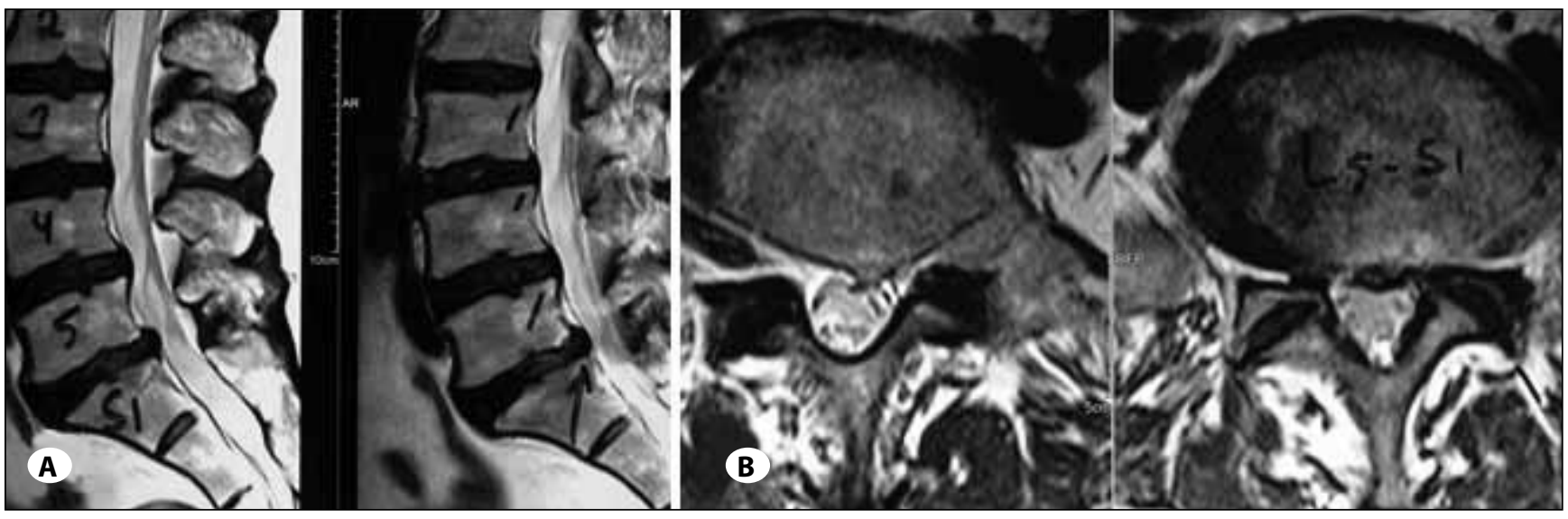

Figure 4: MR images of Patient-4. A) T2-weighted sagittal MR images showing disc protrusions at the L4-5 and L5-S1 levels. B) T2weighted axial MR images showing disc protrusion at the L5-S1 level on the left side.
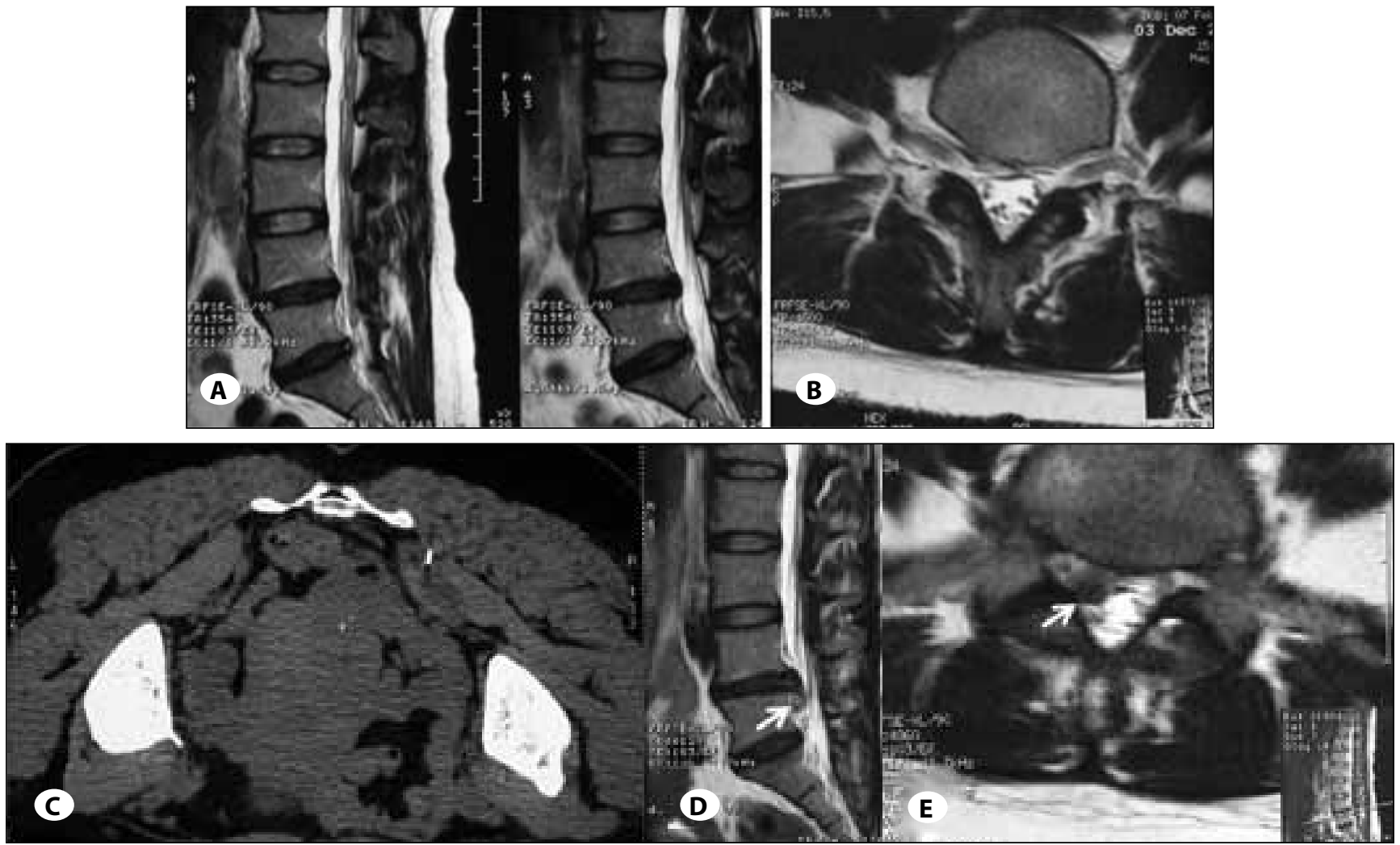

Figure 5: A, B) MR images of Patient 9 showing black discs and slight protrusions at the L4-5 and L5-S1 levels. C) CT images during piriformis injection, right side. D) T2-weighted sagittal MR images (obtained six months after piriformis injection due to leg pain) showing increased disc protrusion at L4-5 level, and disc fragment migrated inferiorly in the spinal canal (arrow). E) T2-weighted axial MR images showing extrude disc piece (arrow) made pressure on right L5 root.

aspect of the greater trochanter of the femur. The gluteal nerves, gluteal vessels, the sciatic nerve composed of the L4, L5, S1, S2 and S3 nerve roots, and the posterior femoral cutaneous nerve pass below the piriformis muscle. There are various anatomical relationships between the sciatic nerve and the piriformis muscle $(1,21,22)$. In 1928, Yeoman presented piriformis syndrome for the first time as a cause of sciatic pain due to the close anatomical relationship between piriformis muscle and the sciatic nerve (28). He thought that the cause was degenerative arthritic changes in the SIJ. Friedberg and Vinke proposed that inflammation of SIJ might lead inflammatory changes of the piriformis muscle, fascia, and the lumbosacral plexus (10). The term "piriformis syndrome" was first coined by Robinson in 1947 (24). 
The piriformis syndrome is primarily caused by a fall, but other potential causes include pyomyositis (5), hypertrophy of the piriformis muscle $(6,9,12)$, dystonia musculorum deformans, anatomical abnormalities of the piriformis muscle or the sciatic nerve $(6,26)$ and fibrosis after deep injections. Secondary causes like irritation of the SIJ or a lump near the sciatic notch have been described. Mayrand et al proposed in a patient with ischial tuberosity avulsion, that it was most likely that changes in muscular tension and gait pattern had contributed to overuse of the piriformis muscle leading to the piriformis syndrome (18). It is thought that the piriformis muscle tendon may be tethering the sciatic nerve, and causing irritation of the nerve because of pressure or decreased blood flow to the nerve. Some investigators consider the piriformis syndrome to be a form of myofascial pain syndrome (23). It may also follow total hip replacement (4) or lumbar disc surgery (19). It was proposed that sciatica after laminectomy may result from impingement of the nerve roots by scar tissue resulting in shortening of the sciatic nerve and rendering it prone to repeated tension and trauma by the piriformis muscle (19).

In general practice, the so-called posttraumatic piriformis muscle syndrome is common. A history of trauma is usually elicited in approximately $50 \%$ of the cases (20). The correct treatment can be started following a thorough investigation into the cause of symptoms. Apart from MR neurography, pelvis MRI remains unable to define a criterion for diagnosis, since asymmetrical size of the piriformis muscle is common in normal people (25). Electromyography is another test for diagnosis, but nerve conduction results reported in the literature were not conclusive and their methods were very controversial. It is well accepted that the impingement of the sciatic nerve should delay the $\mathrm{H}$ reflex as described by Fishman (8), whereas many authors $(2,14)$ have obtained variable results concerning the tibial nerve.

Physical therapy aims at stretching the muscle and reducing the vicious cycle of pain and spasm. It is a mainstay of conservative treatment, usually enhanced by local injections. Cadaveric anatomical $(1,27)$ and surgical anatomical studies (7) have revealed that the sciatic nerve emerges from below the piriformis muscle in almost $90 \%$ of the cases, but various anatomical relationships between the sciatic nerve and the piriformis muscle have been described. The aberrant course or shape of the sciatic nerve through the piriformis muscle can complicate the injection procedure. Physicians have generally been using various techniques such as fluoroscopy, muscle electromyography and ultrasonography to improve the accuracy of needle insertion. It is important to use a technique that is accessible in most clinics, is minimally invasive, can be used quickly, and supports accurate positioning of the needle by visualization of muscular and nervous anatomy. The procedure must also not require specialized equipment such as MRI. It is important to be able to see any aberrant course of the sciatic nerve and also whether there is any change in the structures during injection such as bleeding and/or excessive swelling of the muscle, flowing out of the medicine around the sciatic nerve, and shifting of the sciatic nerve. Therefore CT-guided piriformis injection predominates the other techniques, as we can continue injection despite the patient's minor complaints and prevent under-treatment, or stop the procedure earlier to prevent major complications (16).

Many differential pathophysiological mechanisms were contemplated. The buttock pain and the sciatica that are initially caused by trauma may lead to inflammation and spasm of the muscle (20). Inflammatory substances such as prostaglandin, histamine, bradykinin, and serotonin are released from the inflamed muscle and may irritate the sciatic nerve resulting in a pain-spasm-inflammation-irritation cycle $(15,17)$. Treatment with anti-inflammatory agents, such as corticosteroids, limits the damage and improves recovery (13). The inflamed, spastic or stretched piriformis muscle may compress the sciatic nerve between the muscle and the pelvis $(24,26)$. The $8-10 \mathrm{cc}$ volume increase of the piriformis muscle did not cause any exacerbation of our patients' symptoms such as pain or numbness. It can also be discussed why the injection heals pain in all of the patients in three days. In light of foregoing it seems that the effect of corticosteroids is not clear, as its effect to reduce inflammation to limit the spread of damage appears to be in conflict with the need to permit inflammation to promote regeneration. We believe that only local anesthetic agents may break the pain-spasminflammation-irritation cycle in the short term, and together with steroids they may reverse all long-term inflammatory effects of trauma in the muscle and in and/or around the sciatic nerve. This issue should be subject to further preclinical and clinical investigations and studies.

Filler and his colleagues reported following 8 month to 6 year observations in 162 patients with the piriformis syndrome who received a piriformis injection with open-MRI that $23 \%$ of the patients recovered, $37 \%$ experienced a recurrence after the $2^{\text {nd }}$ injection and $16 \%$ did not respond to the treatment (7). Temporary neural deficits or pain symptoms in the late period after the piriformis injection have also not been reported in the literature. There was temporary hypoesthesia that healed in 6-8 hours in some of our patients. Our observations from 13 months to 2 years found that 1 patient was operated 6 months after the injection because of lumbar disk hernia that was irrelevant to the piriformis syndrome. Only one of the patients did not respond the treatment (10\%) and this is compatible with the literature.

In summary, we reviewed the causes, clinical evaluations, and pathophysiological mechanisms of piriformis syndrome in this study. It can be proposed that the physical activity, lifestyle, and habituations of the patient that could be an important factor with an underlying inadaptable anatomy can cause piriformis syndrome, besides the relation between the sciatic nerve and piriformis muscle. We found that piriformis injection guided by computed tomography is an effective and safe method for the treatment of piriformis syndrome. It is faster and easier than MRI-guided procedures, and needs less specialized equipment. The study shows that piriformis 
injection should be considered with CT and/or MRI imaging of the sciatic nerve, piriformis muscle and related region before the procedure, prior to surgical treatment.

\section{REFERENCES}

1. Beason LS, Anson BJ: The relation of the sciatic nerve and its subdivisions to the piriformis muscle. Anat Record 70:1-5, 1937

2. Benson ER, Schutzer SF: Posttraumatic piriformis syndrome: Diagnosis and results of operative treatment. J Bone Joint Surg Am 81:941-949, 1999

3. Bernard TN Jr, Kirkaldy-Willis WH: Recognizing specific characteristics of nonspecific low back pain. Clin Orthop Relat Res 217:266-280, 1987

4. Cameron HU, Noftal F: The piriformis syndrome (editorial). Can J Surg 31:210, 1988

5. Chen WS: Bipartite piriformis muscle: an unusual cause of sciatic nerve entrapment. Pain 58:269-272, 1994

6. Chen WS: Sciatica due to piriformis pyomyositis. J Bone Joint Surg 74:1546-1548, 1992

7. Filler AG, Haynes J, Jordan SE, Prager J, Villablanca JP, Farahani K, McBride DQ, Tsuruda JS, Morisoli B, Batzdorf U, Johnson JP: Sciatica of nondisc origin and piriformis syndrome: Diagnosis by magnetic resonance neurography and interventional magnetic resonance imaging with outcome study of resulting treatment. J Neurosurg Spine 2:99-115, 2005

8. Fishman LM, Zybert PA: Electrophysiologic evidence of piriformis syndrome. Arch Phys Med Rehabil 73:359-364,1992

9. Fishman SM, Caneris OA, Bandman TB, Audette JF, Borsook $\mathrm{D}$ : Injection of the piriformis muscle by fluoroscopic and electromyographic guidance. Reg Anesth Pain Med 23: 554-559, 1998

10. Friedberg $A H$, Vinke $T H$ : Sciatica and sacroiliac joint. J Bone Joint Surg (Am) 16:126-136, 1934

11. Hallin RP: Sciatic pain and the piriformis muscle. Postgrad Med 74:69-72, 1983

12. Hanania M, Kitain E: Perisciatic injection of steroid for the treatment of sciatica due to piriformis syndrome. Reg Anesth Pain Med 23:223-228, 1998

13. Hirschberg DL, Yoles E, Belkin M, Schwartz M: Inflammation after axonal injury has conflicting consequences for recovery of function: Rescue of spared axons is impaired but regeneration is supported. J Neuroimmunol 50:9-16, 1994
14. Hugues SS, Goldstein MN, Hicks DG, Pellegrini VD Jr: Extrapelvic compression of the sciatic nerve. An unusual cause of pain about the hip: Report of five cases. J Bone and Joint Surg 74:1553-1559, 1992

15. Jankiewicz JT, Hennrikus WL, Houkom JA: The appearance of the piriformis muscle in computed tomography and magnetic resonance imaging: A case report and review of the literature. Clin Orthop 262:205-209, 1991

16. Kabataş S, Gümüş B, Yılmaz C, Caner H: CT-guided corticosteroid injection as a therapeutic management for the pyriformis syndrome: Case report. Turk Neurosurg 18: 307-310, 2008

17. Lynn B: Cutaneous hyperalgesia. Br Med Bull 33:103-108, 1977

18. Mayrand N, Fortin J, Descarreaux M, Normand MC: Diagnosis and management of posttraumatic piriformis syndrome: $A$ case study. J Manipulative Physiol Ther 29:486-491, 2006

19. Mizuguchi T: Division of the piriformis muscle for the treatment of sciatica: Postlaminectomy syndrome and osteoarthritis of the spine. Arch Surg 111:719-722,1976

20. Pace JB, Nagle D: Piriformis syndrome. West J Med 124: 435-439, 1976

21. Parziale JR, Hudgins $H$, Fishman LM: The piriformis syndrome. Am J Orthop 25:819-823, 1996

22. Pecina M: Contribution to the etiological explanation of the piriformis syndrome. Acta Anat 105:181-187, 1979

23. Porta M: A comparative trial of botulinum toxin type $A$ and methylprednisolone for the treatment of myofascial pain syndrome and pain from chronic muscle spazm. Pain 85: 101-105, 2000

24. Robinson D: Piriformis syndrome in relation to sciatic pain. Am J Surg 73:355-358, 1947

25. Russell JM, Kransdorf MJ, Bancroft LW, Peterson JJ, Berquist $\mathrm{TH}$, Bridges MD: Magnetic resonance imaging of the sacral plexus and piriformis muscles. Skeletal Radiol 37:709-713, 2008

26. Sayson SC, Ducey JP, Maybrey JB, Wesley RL, Vermilion D: Sciatic entrapment neuropathy associated with an anomalous piriformis muscle. Pain 59:149-152, 1994

27. Windisch G, Braun EM, Anderhuber F: Piriformis muscle: Clinical anatomy and consideration of the piriformis syndrome. Surg Radiol Anat 29:37-45, 2007

28. Yeoman W: The relation of arthritis of the sacroiliac joint to sciatica, with an analysis of 100 cases. Lancet 2:1119-1122, 1928 